\title{
Correction to: Experimental performance evaluation of an impinging jet with fins type solar air heater
}

\author{
Abhishek Kumar Goel ${ }^{1,2}$ (D) Shailendra Narayan Singh ${ }^{1}$
}

Published online: 18 February 2021

(C) Springer-Verlag GmbH Germany, part of Springer Nature 2021

Correction to: Environmental Science and Pollution Research https://doi.org/10.1007/s11356-020-12193-x

The correct Authors affiliations are presented in this paper.

The original article has been corrected.

Publisher's note Springer Nature remains neutral with regard to jurisdictional claims in published maps and institutional affiliations.

The online version of the original article can be found at https://oi.org/ $10.1007 / \mathrm{s} 11356-020-12193-\mathrm{x}$

Abhishek Kumar Goel akgism2013@gmail.com

1 Department of Mechanical Engineering, RKGIT, Ghaziabad, Uttar, Pradesh 201003, India

2 Department of Mechanical Engineering, Indian Institute of, Technology (Indian School of Mines), Dhanbad, Jharkhand 826004, India 